\title{
PENGARUH JENIS KAYU DAN SISTEM SAMBUNGAN TERHADAP DESAIN MEBEL KAYU
}

\section{(The Effect of Wood Species and Joining System on Wooden Furniture Design)}

\author{
Eko Agung Syaputra \& Imam Damar Djati \\ Fakultas Seni Rupa dan Desain, Institut Teknologi Bandung \\ Jl. Ganesha No. 10 Bandung, 40132, Telp. (022) 2504252, Faks. (022) 2500935 \\ E-mail: ekoagungs1996@gmail.com
}

Diterima 18 Juni 2020, direvisi 13 April 2021, disetujui 22 Juni 2021

\begin{abstract}
Wooden furniture is one of strategic commodities that have a dominant contribution to Indonesian economy compared to other furniture material. Joining system in the wooden furniture is the weakest construction point, therefore detail analysis is needed to study factors affecting construction capacity and effectiveness of wooden joining system. The aim of this research was to determine the effect of wood species and joining system on wooden furniture design especially compression strength on joining point. The wood species used were jati (Tectona grandis L. f.), kapur (Dryobalanops sp.), meranti (Shorea sp.), manglit (Manglietia glauca Bl.), and sengon (Falcataria moluccana $L$.). The joining system applied in this study were tenon and mortise, lap, and dovetail joints. The results showed that teak wood exhibited the highest compression strength, while sengon wood exhibits the lowest compression strength on all wood joining systems compared to other wood species studied. In term of wood joining systems, the lap joint exhibited the highest compression strength, whereas tenon and mortise joint exhibited the lowest performance.
\end{abstract}

Keywords: Furniture design, joint, wood species, tenon mortise, lap, dovetail

\begin{abstract}
ABSTRAK
Produk mebel kayu merupakan salah satu komoditas strategis yang memiliki kontribusi dominan dibandingkan material mebel lain bagi ekonomi Indonesia. Pada produk mebel, sistem sambungan merupakan titik terlemah dalam konstruksinya, sehingga diperlukan analisis terperinci faktor-faktor yang mempengaruhi kapasitas konstruksi serta efektifitas dalam sistem sambungan kayu. Tujuan penelitian ini adalah mempelajari pengaruh jenis kayu dan sistem sambungan terhadap desain mebel kayu khususnya kekuatan tekan pada titik sambungan. Jenis kayu yang digunakan dalam penelitian ini adalah jati (Tectona grandis L. f.), kapur (Dryobalanops sp.), meranti (Shorea sp.), manglit (Manglietia glauca Bl.), dan sengon (Falcataria moluccana L.), sedangkan sistem sambungan yang dibuat adalah sambungan purus lubang, pangkuan, dan ekor burung. Hasil penelitian menunjukkan bahwa kayu jati memiliki kekuatan tekan tertinggi, sedangkan kayu sengon memiliki kekuatan tekan terendah pada semua sistem sambungan disbanding jenis kayu lainnya yang dipelajari. Sistem sambungan pangkuan memiliki kekuatan tekan tertinggi dan sambungan purus lubang memiliki kekuatan tekan terendah.

Kata kunci: Desain mebel, sambungan, jenis kayu, purus lubang, pangkuan, ekor burung
\end{abstract}

\section{PENDAHULUAN}

Sebagai produk yang memiliki nilai tambah tinggi serta berdaya saing global, mebel merupakan salah satu komoditas strategis bagi perekonomian Indonesia. Indonesia memiliki kekayaan sumber daya alam yang relatif melimpah, serta didukung oleh keragaman corak dan desain yang mampu memberikan ciri industri lokal pada setiap wilayah. Berdasarkan bahan bakunya, mebel dapat terbuat dari kayu, rotan, bambu, logam, plastik, dan material lainnya. Menurut catatan Kementerian Perindustrian (2015), produk mebel kayu mencapai 80\% dari total seluruh produksi, sedangkan mebel yang bermaterial rotan dan bambu berkontribusi sebasar 11\%, mebel bermaterial logam $8 \%$, sedangkan mebel plastik hanya mencapai $2 \%$ dari keseluruhan produksi mebel Indonesia. Berdasarkan data World Integrated Trade Solution (2017) perdagangan internasional mebel kayu memiliki kontribusi yang dominan dibandingkan mebel bermaterial lain, yakni mencapai 71\%, sementara, kontribusi mebel logam sebesar 22\%, mebel plastik sebesar 3\%, dan untuk material lainnya sebesar 4\% (Kementerian Perindustrian, 2015).

Wilayah Indonesia memiliki kawasan hutan tropis dengan luas mencapai 120,6 juta ha, dengan 
pengalokasian hutan produksi mencapai 68,8 juta hektar, hutan konservasi 22,1 juta hektar dan hutan lindung 29,7 juta hektar. Jenis kayu yang dimanfaatkan oleh industri pengolahan kayu hampir seluruhnya berasal dari hutan produksi alam (Kementerian Lingkungan Hidup dan Kehutanan, 2018). Dalam pemanfaatan sebagai material produksi, kayu digolongkan ke dalam lima kelas kuat berdasarkan berat jenis, keteguhan lengkung mutlak, dan keteguhan tekan mutlak (Sunardianto, 2012).

Secara umum sistem sambungan merupakan titik terlemah dalam konstruksi mebel, sehingga perlu adanya analisis terperinci mengenai faktor-faktor yang mempengaruhi kapasitas konstruksi serta efektivitas dalam sistem sambungan kayu (Tankut, 2010). Produk mebel kayu akan dikenakan banyak jenis beban selama proses penggunaan, sehingga penerapan sistem konstruksi yang kurang sesuai pada produk mebel kayu akan berpotensi menimbulkan efek tegangan atau kerusakan pada bagian-bagian yang lemah, seperti pada titik sambungan (Cai \& Wang, 1993).

Penelitian ini bertujuan untuk memahami hubungan kelas kuat kayu dan sistem sambungan terhadap desain mebel kayu, sehingga dapat digunakan sebagai acuan dalam mendesain mebel kayu. Dalam penelitian ini diperoleh data berupa perbandingan kekuatan antara jenis kayu dan sistem sambungan yang berbeda. Selain itu, dalam studi ini juga dilakukan analisis bentuk kerusakan yang terjadi pada sistem sambungan yang diperlukan untuk memahami karakteristik dari setiap sistem sambungan yang akan diterapkan dalam desain mebel kayu.

\section{BAHAN DAN METODE}

\section{A. Bahan dan Peralatan}

Bahan yang digunakan dalam penelitian ini adalah kayu jati (Tectona grandis L. f.) dengan kelas kuat II, kapur (Dryobalanops sp.) dengan kelas kuat II, meranti (Shorea sp.) dengan kelas kuat III, manglid (Manglietia gluaca Bl.) dengan kelas kuat IV, dan sengon (Falcataria moluccana L.) dengan kelas kuat V. Selain itu, terdapat komponen pasak (dowel) dari kayu ramin (Gonystylus bancanus (Miq.) Kurz.) yang berfungsi sebagai pengikat dalam sistem sambungan. Peralatan yang digunakan adalah jangka sorong, bench surface planer, thicknesser planer, table saw, band saw, miter saw, drill press, matric feeler gange, digital moisture meter, dan Universal Testing Machine (UTM) Merk Tensilon RTF.

\section{B. Metode}

Pada penelitian ini terdapat tiga sistem sambungan yang dijadikan sebagai fokus penelitian yang umumnya diterapkan pada industri mebel kayu, serta mampu mengindikasikan adanya patahan, geseran, serta retakan ketika dilakukan proses pengujian. Sistem sambungan yang diterapkan pada pengujian ini yaitu sambungan tenon and mortise, lap, dan dovetail.

Tahapan proses penelitian yang dilakukan adalah:

1. Persiapan Bahan Kayu dan Pembuatan Sambungan

Lima jenis kayu dipotong dengan ukuran $5 \mathrm{~cm} \mathrm{x}$ $3,5 \mathrm{~cm} \times 22 \mathrm{~cm}$. Jumlah total keseluruhannya 45 pasang sampel. Selain menggunakan tiga sambungan yang berbeda, pada penelitian ini juga menggunakan kuncian berupa dowel yang terbuat dari material kayu ramin dengan ukuran diameter $8 \mathrm{~mm}$. Kayu ramin dipilih sebagai dowel, karena memiliki arah serat kayu yang relatif lurus atau terpadu. Untuk tingkat ketelitian celah sambungan $<1 \mathrm{~mm}$. Jumlah sampel uji setiap jenis kayu dan tipe sambungan sebagai Tabel 1. Hasil pembuatan sampel uji dari setiap jenis kayu yang dipilih secara acak disajikan pada Gambar 4.

\section{Pengujian Kekuatan Tekan Sambungan Kayu}

Dalam menentukan batas kuat sistem sambungan kayu digunakan pengujian tekan pada tiga sistem sambungan kayu yang telah diperkuat dengan dowel berukuran $8 \mathrm{~mm}$. Pada sistem sambungan tenon and mortise digunakan satu dowel, sedangkan pada sistem sambungan lap dan dovetail digunakan dua dowel. Sampel sistem sambungan ini diuji menggunakan UTM dengan kecepatan pembebanan $2 \mathrm{~mm} /$ menit.

Tabel 1. Jumlah sampel uji

Table 1. Number of tested samples

\begin{tabular}{lccc}
\hline \multicolumn{1}{c}{$\begin{array}{c}\text { Jenis kayu } \\
\text { (Wood species) }\end{array}$} & \multicolumn{2}{c}{ Jenis sambungan (Types of joint) } \\
\cline { 2 - 4 } & Tenon and mortise & Lap & Dovetail \\
\hline Jati (Tectona grandis L. f.) & 3 sampel & 3 sampel & 3 sampel \\
Kapur (Dryobalanops sp.) & 3 sampel & 3 sampel & 3 sampel \\
Meranti (Shorea sp.) & 3 sampel & 3 sampel & 3 sampel \\
Manglid (Manglietia glauca Bl.) & 3 sampel & 3 sampel & 3 sampel \\
Sengon (Falcataria moluccana L.) & 3 sampel & 3 sampel & 3 sampel \\
\hline
\end{tabular}




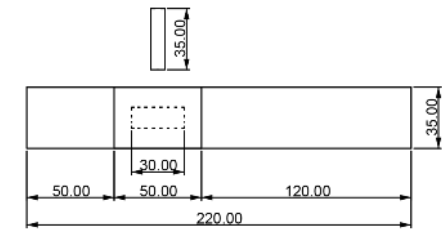

Tampak atas (Top view)

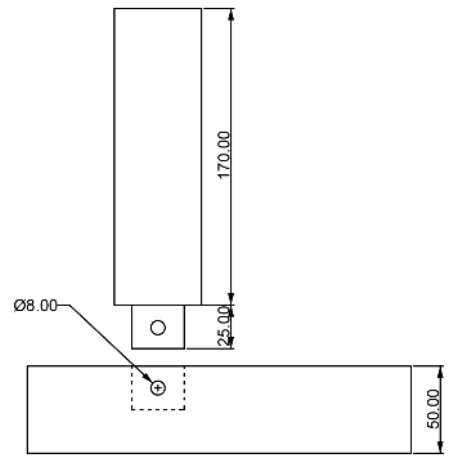

Tampak depan (Front view)
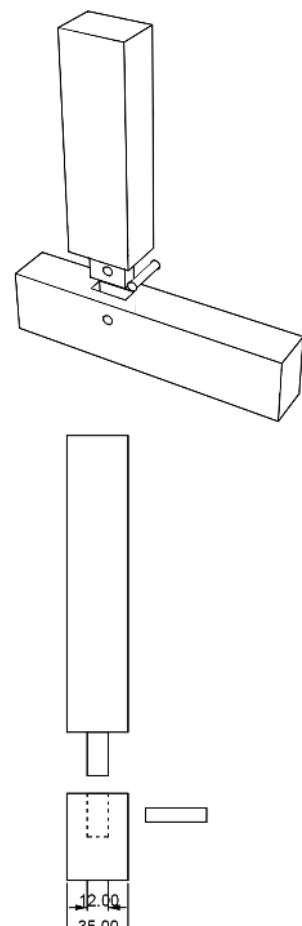

Tampak samping (Side view)

Gambar 1. Proyeksi pada sambungan tenon and mortise

Figure 1. Projection on tenon and mortise joint
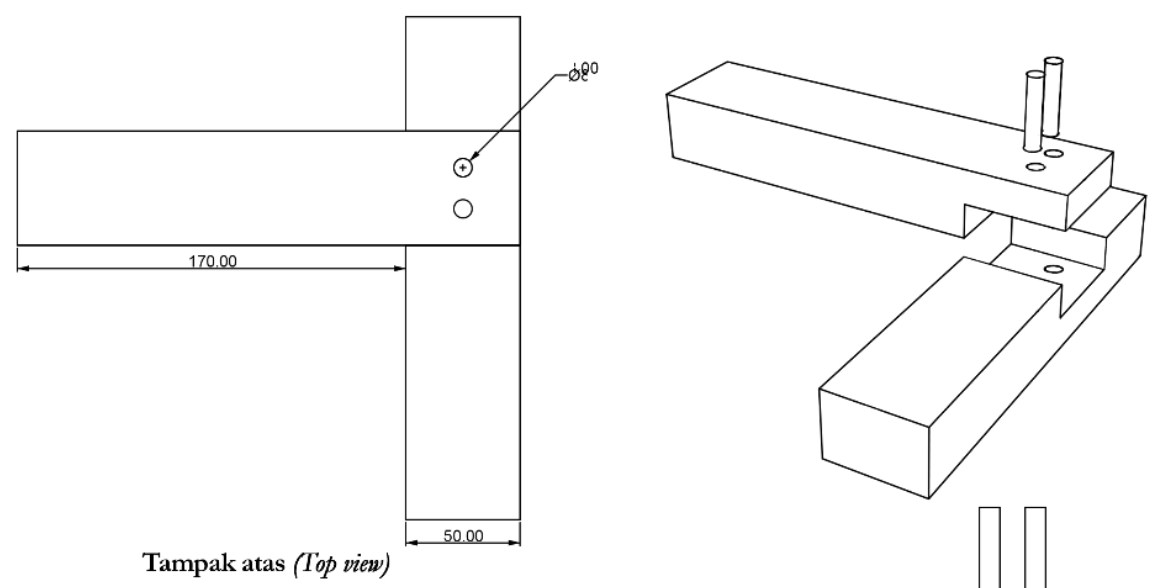

Tampak atas (Top view)
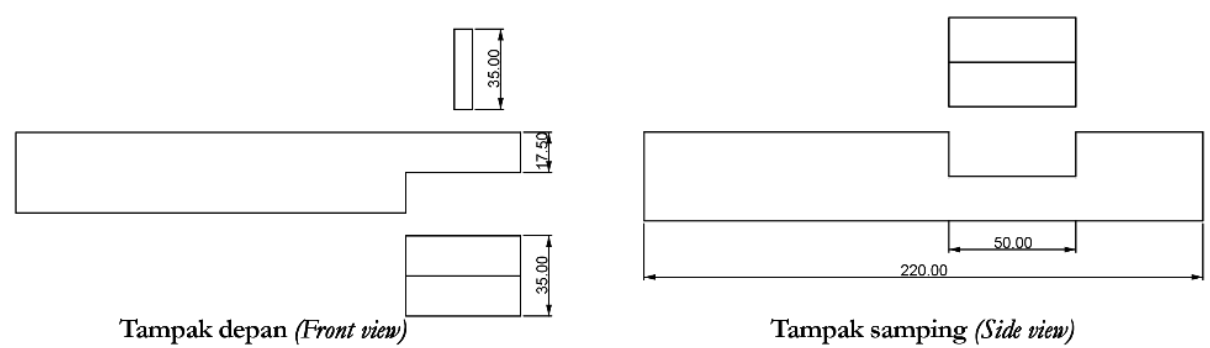

Tampak samping (Side view)

Gambar 2. Proyeksi pada sambungan lap

Figure 2. Projection on lap joint 

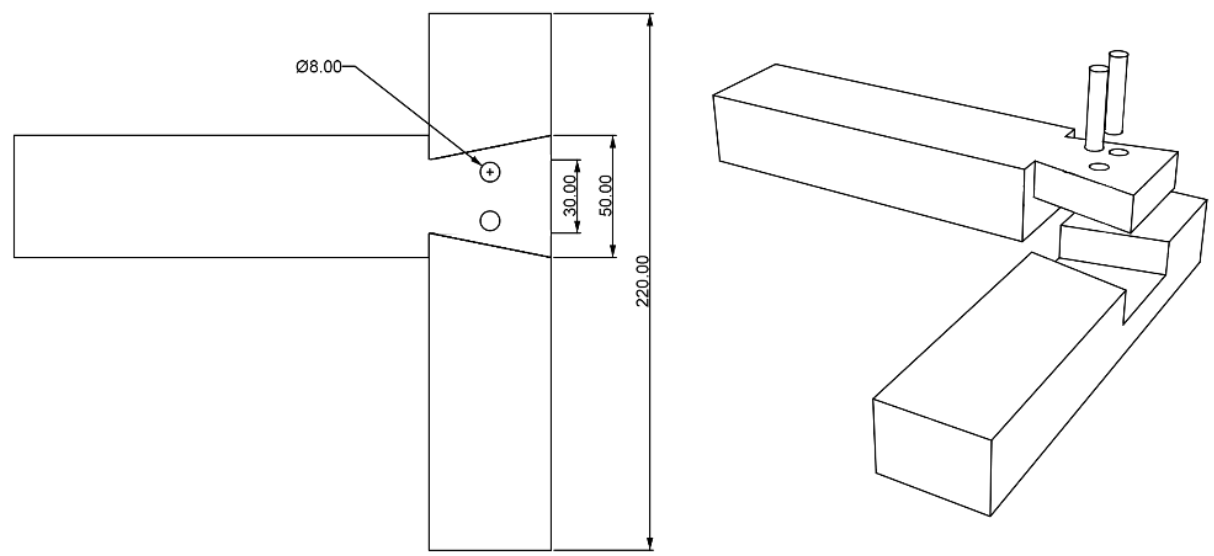

Tampak atas (Top view)

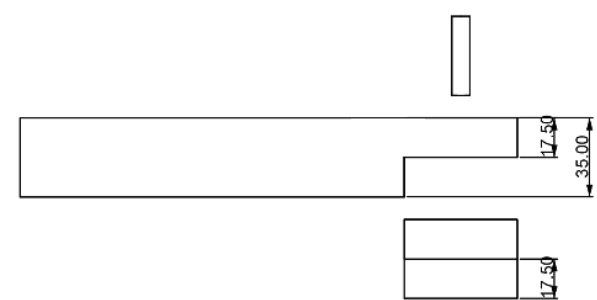

Tampak depan (Front view)

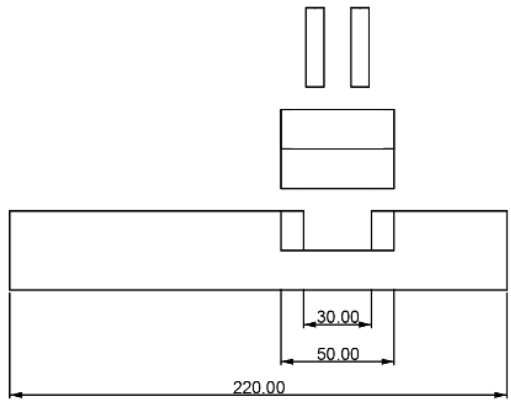

Tampak samping (Side view)

Gambar 3. Proyeksi pada sambungan dovetail

Figure 3. Projection on dovetail joint

Jati (Tectona grandis L. f.)

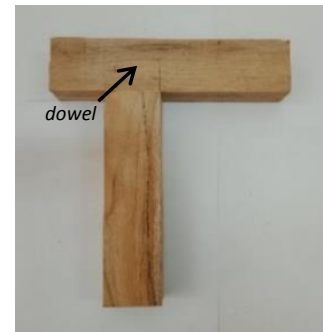

Tenon and mortise

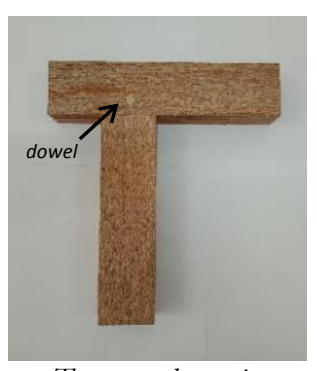

Tenon and mortise

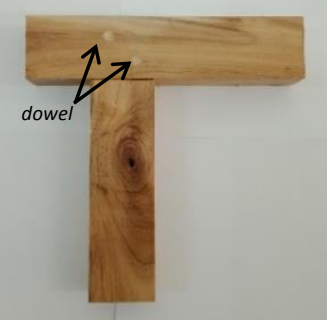

Lap joint

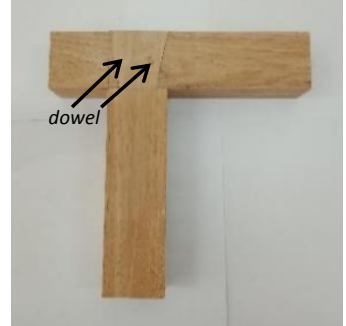

Dovetail joint

Kapur (Dryobalanops sp.)

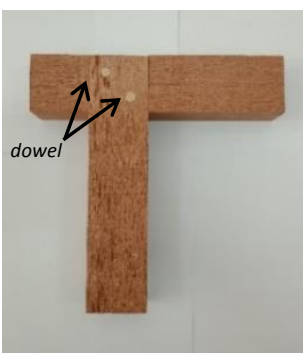

Lap joint

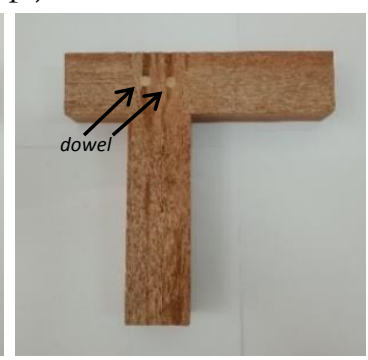

Dovetail joint 


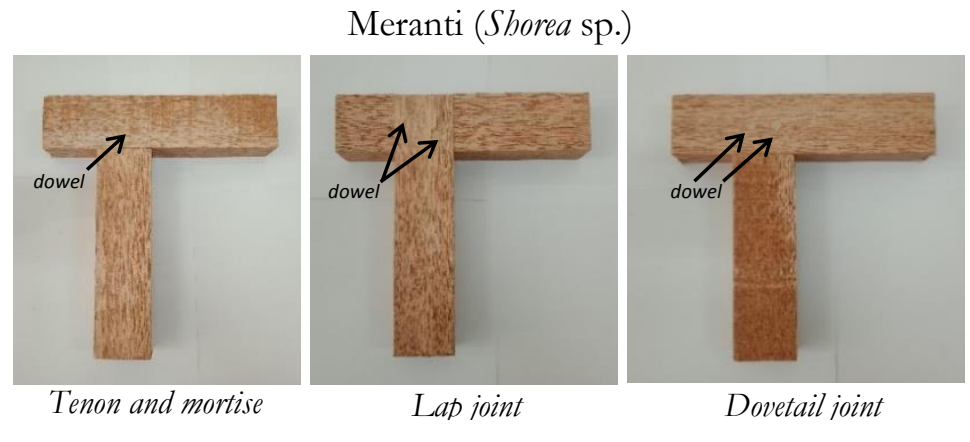

Manglid (Manglietia glauca Bl.)

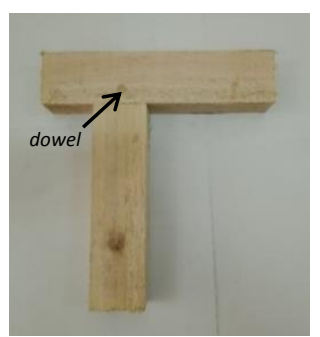

Tenon and mortise

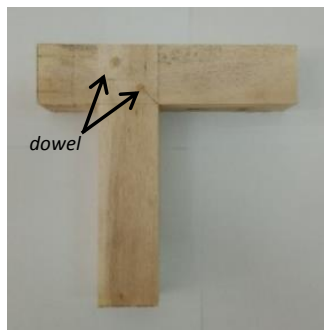

Lap joint

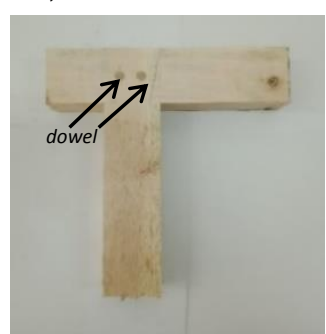

Dovetail joint

Sengon (Falcataria moluccana L.)

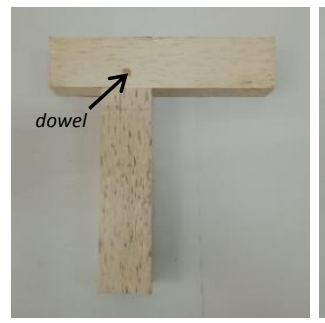

Tenon and mortise

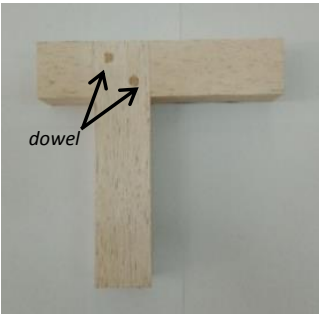

Lap joint

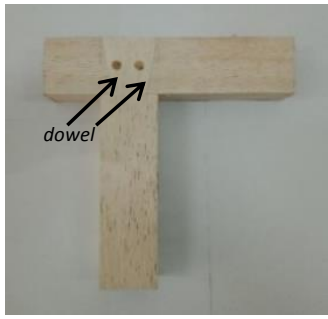

Dovetail joint

Gambar 4. Sampel uji sambungan kayu

Figure 4. Wood joining samples

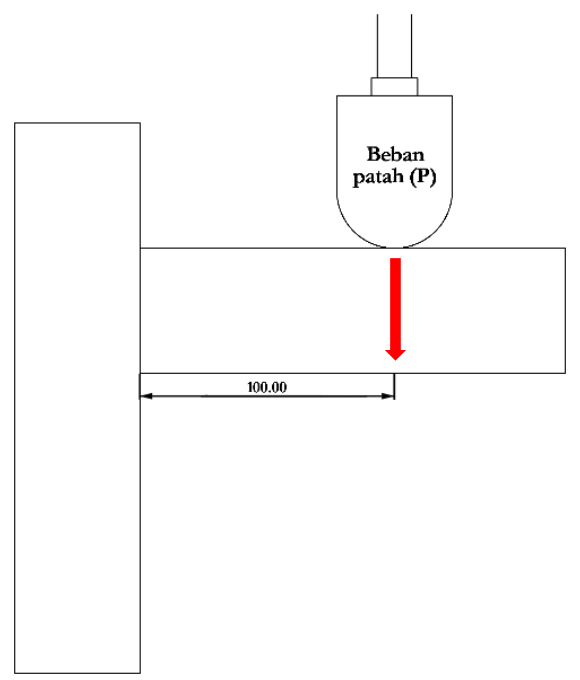

Gambar 5. Skema pengujian kuat tekan sampel sambungan kayu Figure 5. Schematic compression testing of the wood joint samples 


\section{Analisis Data}

Data hasil penelitian dianalisis dengan membandingkan kekuatan tekan dan kerusakan pada setiap komponen sambungan. Melalui hasil analisis ini diharapkan mampu mengetahui pengaruh antara jenis kayu dan sistem sambungan dalam proses perancangan mebel sehingga mampu meminimalisir tingkat kegagalan pada proses prototyping maupun produksi secara massal. Selain itu, identifikasi pengaruh kelas kuat kayu dan sistem sambungan terhadap desain mebel bertujuan untuk menghasilkan mebel yang memiliki harmonisasi antara bentuk, material, dan sistem konstruksinya. Melalui kesesuaian tersebut dapat menghasilkan produk mebel yang tidak hanya memiliki kualitas desain yang baik, namun juga memiliki masa pakai mebel lebih panjang, serta menghasilkan produk yang lebih efektif dalam hal waktu dan lebih efisien dalam hal penggunaan material.

\section{HASIL DAN PEMBAHASAN}

Pada Tabel 2. dapat dilihat bahwa titik tekan tertinggi kayu jati terjadi pada sistem sambungan lap. Perbedaan cukup signifikan pada kayu jati dengan sistem sambungan tenon and mortise sebesar 100,80 kgf, sedangkan dengan sistem sambungan lapjoint mampu menahan beban rata-rata hingga mencapai $232,85 \mathrm{kgf}$. Sistem sambungan tenon and mortise dengan luas permukaan $9 \mathrm{~cm}^{2}$ memiliki luas permukaan yang lebih kecil dibanding sambungan lap dengan luas $25 \mathrm{~cm}^{2}$ dan dovetail degan luas $20 \mathrm{~cm}^{2}$. Luas permukaan sambungan mempengaruhi besarnya kekuatan sambungan, sehingga tenon and mortise memiliki kekuatan yang paling rendah pada penerapan sambungan kayu jati kelas kuat II.

Pengujian kuat tekan sambungan pada kayu kapur pada Tabel 2, menunjukkan bahwa sistem sambungan tenon and mortise memiliki luas permukaan sambungan yang lebih kecil dibandingkan sambungan lap dan dovetail. Luas permukaan sambungan mempengaruhi besarnya kekuatan sambungan, sehingga tenon and mortise memiliki kekuatan yang paling rendah pada penerapan sambungan kayu kapur kelas kuat II.

Hasil pengujian kekuatan tekan sambungan pada kayu meranti ditunjukkan pada Tabel 2. yang memiliki kemiripan dengan kayu kapur dan nilai rata-rata kekuatan tekan tertinggi pada sistem sambungan lap yaitu sebesar 125,72 kgf. Perbedaan antara kayu kapur dan kayu meranti terletak pada kekuatan sistem sambungan tenon and mortise yang memiliki kekuatan lebih kecil dibandingkan sambungan dovetail. Hal ini berbanding terbalik dengan sistem sambungan pada kayu kapur, yang menunjukkan bahwa luas sambungan tidak berbanding lurus dengan kekuatan tekan sambungan.

Pada sistem sambungan kayu manglid menunjukkan hasil nilai kekuatan tekan rata-rata hampir mirip pada setiap sistem sambungannya. Haygreen dan Bowyer (1996) dan Panshin \& de Zeew (1980) mengemukakan bahwa sebagian besar sel-sel kayu berdinding tipis menghasilkan kerapatan yang rendah. Kayu manglid memiliki kekuatan rata-rata sambungan yang hampir sebanding dengan kayu kapur pada sistem sambungan lap. Pada sistem sambungan tenon and mortise, kayu manglid memiliki kekuatan yang lebih besar dibandingkan meranti dan

Tabel 2. Data uji tekan sambungan kayu

Table 2. Wood joint compression test data

\begin{tabular}{clrr}
\hline $\begin{array}{c}\text { Jenis kayu } \\
\text { (Wood species) }\end{array}$ & \multicolumn{1}{c}{$\begin{array}{c}\text { Jenis sambungan } \\
\text { (Types of joint) }\end{array}$} & $\begin{array}{c}\text { Gaya } \\
\text { (Force, N) }\end{array}$ & $\begin{array}{c}\text { Kilogram-gaya } \\
\text { (Kilogram-force, kgf) }\end{array}$ \\
\hline Jati (Tectona grandis L. f.) & Tenon and mortise & 988,26 & 100,80 \\
& Lap joint & $2.282,87$ & 232,85 \\
& Dovetail & $1.928,45$ & 196,70 \\
Kapur (Dryobalanops sp.) & Tenon and mortise & 921,95 & 94,03 \\
& Lap joint & $1.237,46$ & 126,22 \\
& Dovetail & 651,92 & 66,49 \\
Meranti (Shorea sp.) & Tenon and mortise & 675,97 & 68,95 \\
& Lap joint & $1.232,60$ & 125,72 \\
Manglid (Manglietia glauca Bl.) & Dovetail & 996,84 & 101,68 \\
& Tenon and mortise & 755,21 & 77,03 \\
& Lap joint & $1.181,22$ & 120,48 \\
Sengon (Falcataria moluccana L.) & Dovetail & $1.002,77$ & 102,28 \\
& Tenon and mortise & 355,73 & 36,28 \\
& Lap joint & 465,65 & 47,49 \\
& Dovetail & 568,61 & 57,90 \\
\hline
\end{tabular}




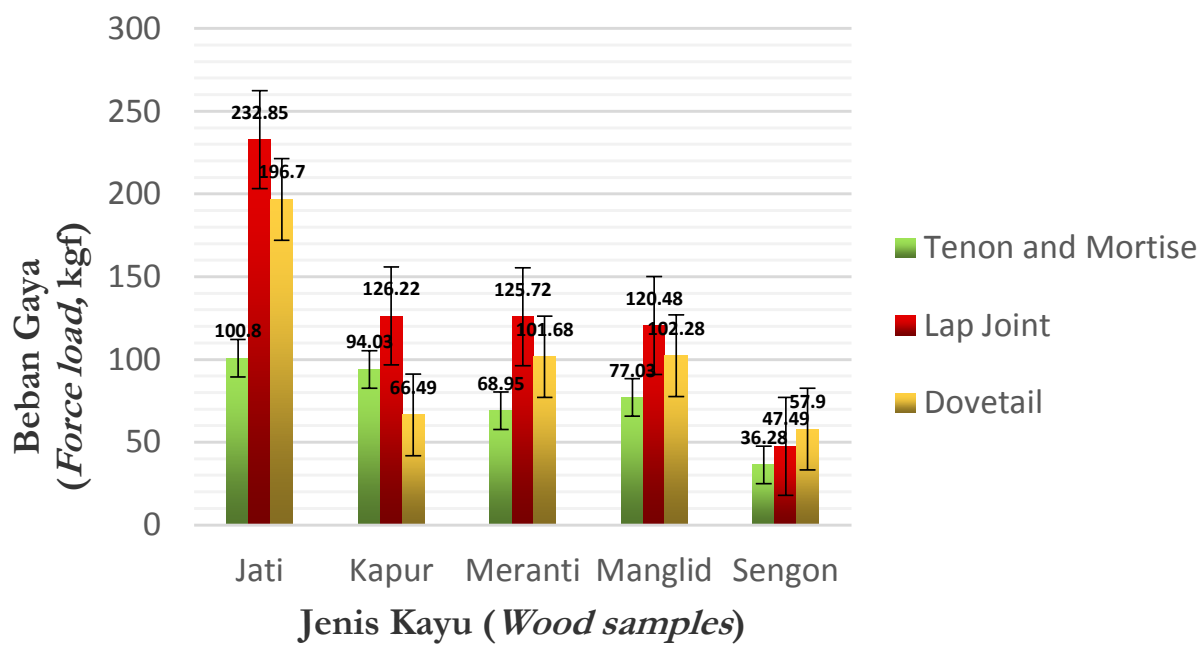

\section{Gambar 6. Akumulasi beban maksimum pada sampel sambungan kayu Figure 6. Maximum load accumulation in wood joining samples}

sengon, yaitu 77,03 kgf. Pada sistem sambungan dovetail, kayu manglid memiliki kekuatan yang lebih besar dibandingkan kayu kapur dan sengon.

Sistem sambungan kayu sengon memiliki nilai rata-rata kekuatan tekan yang cukup rendah pada setiap sambungannya dibandingkan dengan variabel material uji yang lain. Hal tersebut dikarenakan kayu sengon memiliki nilai kerapatan dan berat jenis kayu yang paling rendah dibandingkan dengan jenis kayu yang lain. Namun didapatkan perbedaan dari hasil uji pada kayu sengon yang menunjukkan bahwa sistem sambungan dovetail dinilai cukup efektif dalam menahan beban lebih tinggi dibandingkan sistem sambungan tenon and mortise dan lap

Berdasarkan hasil uji kekuatan tekan menggunakan UTM, didapatkan nilai tertinggi pada sambungan lap dengan material jati sebesar 232,85 kgf, sedangkan nilai paling rendah pada sambungan tenon and mortise dengan kayu sengon sebesar 36,28 kgf (Gambar 6.). Rata-rata sambungan lap memiliki nilai ketahanan terhadap gaya lebih besar dibandingan sistem sambungan yang lain. Nilai rata-rata ketahanan tertinggi setelah sambungan lap adalah dovetail. Hal tersebut dikarenakan sambungan lap dan dovetail memiliki luas permukaan sambungan yang tidak jauh berbeda dengan selisih luas permukaan sebesar $5 \mathrm{~cm}^{2}$, sehingga hasil kekuatan dari kedua sistem sambungan tersebut tidak jauh berbeda.

Pusat gravitasi tubuh pada saat duduk tegak, berada disekitar $22 \mathrm{~cm}$ di muka dan $24 \mathrm{~cm}$ diatas titik acuan duduk (Gambar 7.). Pada prinsipnya mebel akan dikenakan banyak jenis beban selama proses penggunaan. Oleh karena itu penerapan sistem konstruksi yang kurang sesuai pada produk mebel kayu, akan berpotensi terjadinya efek tegangan atau kerusakan pada bagian - bagian yang lemah, seperti pada titik sambungan. Pada Gambar 8-10 disajikan analisis kerusakan fisik pada sistem sambungan mabel kayu.

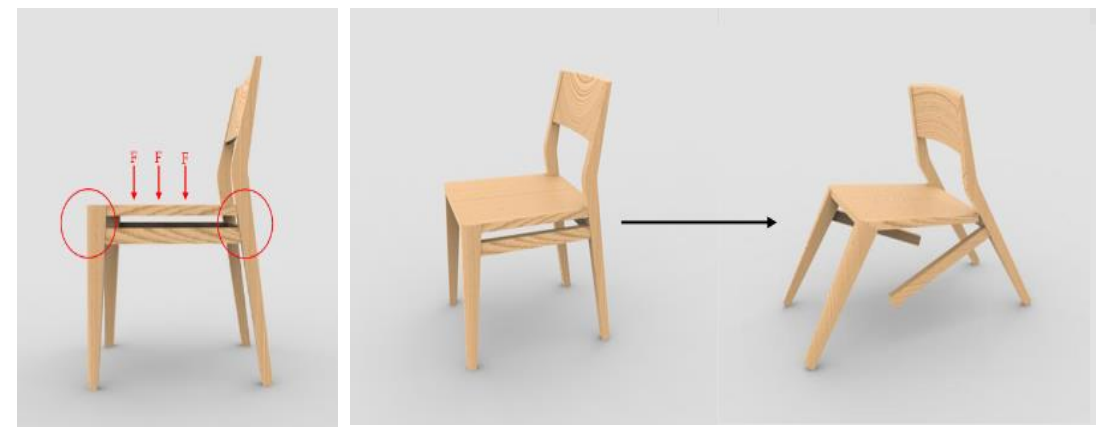

Gambar 7. Analisis kerusakan pada sistem sambungan mebel kayu Figure 7. Analysis of damage to the wooden furniture joining system 


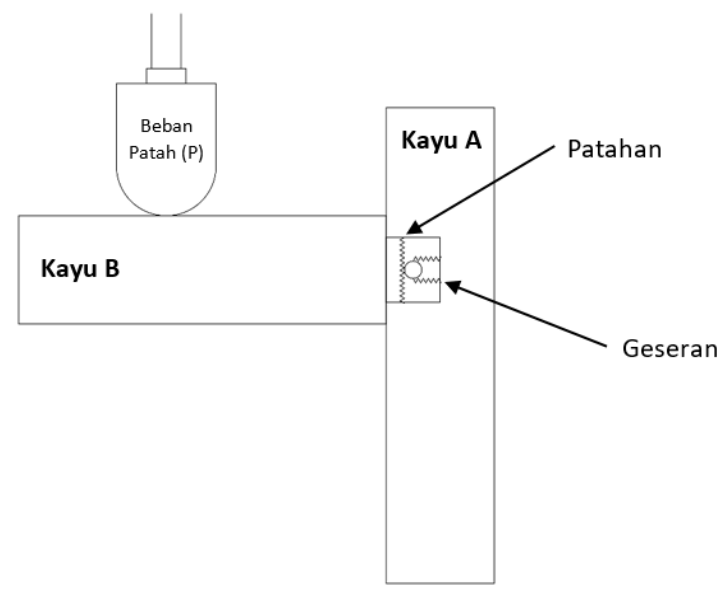

Gambar 8. Analisis kerusakan fisik pada sambungan tenon and mortise Figure 8. Analysis of physical damages on tenon and mortise joint

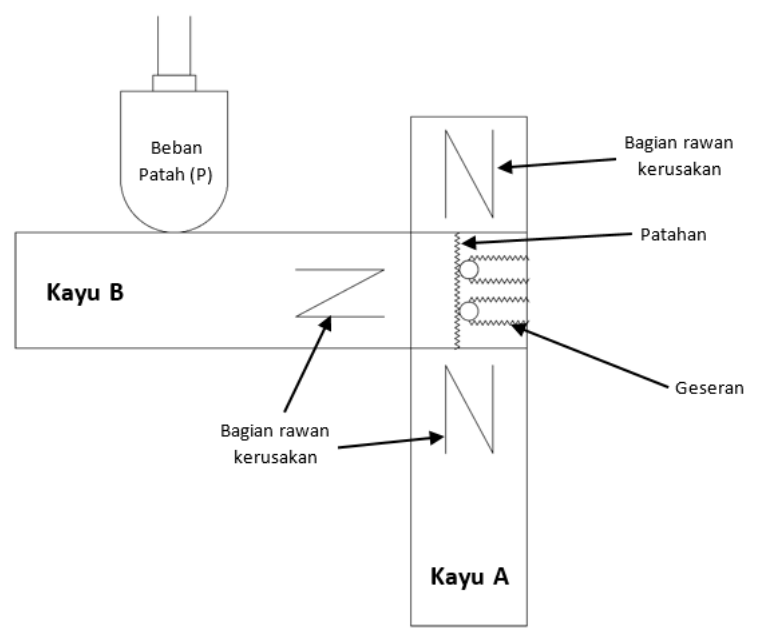

Gambar 9. Analisis kerusakan fisik pada sambungan lap

Figure 9. Analysis of physical damages on lap joint

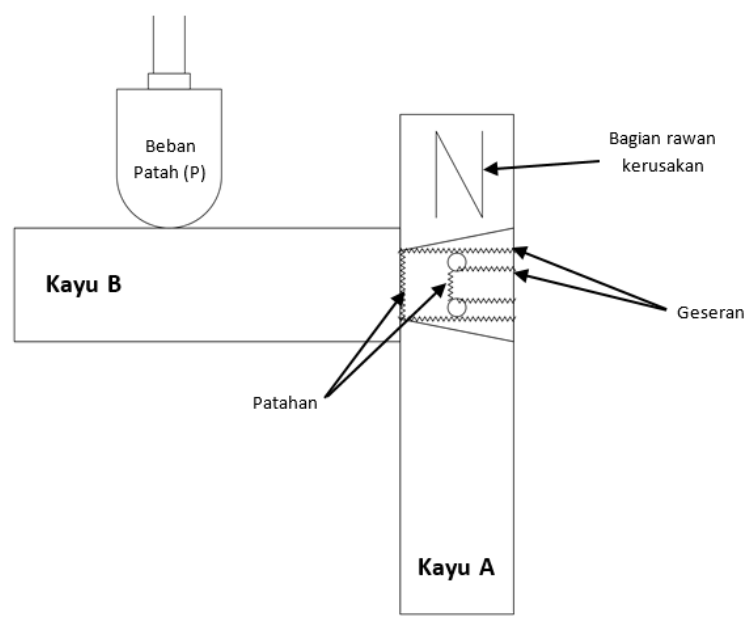

Gambar 10. Analisis kerusakan fisik pada sambungan dovetail

Figure 10. Analysis of physical damages on dovetail joint 


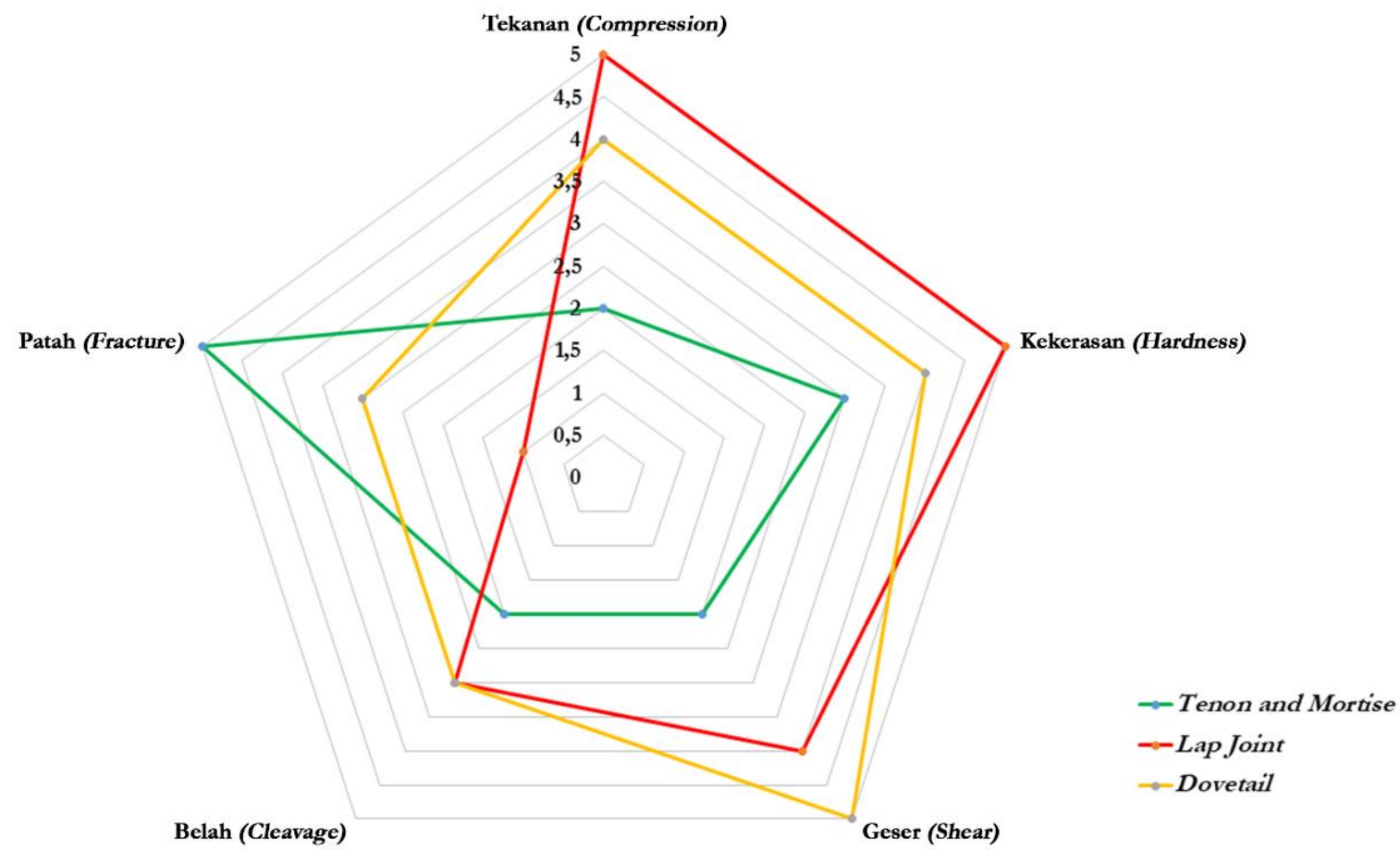

Gambar 11. Analisis bentuk kerusakan pada sambungan kayu

Figure 11. Analysis of the form of damage to wooden joints

Pada penelitian ini juga didapatkan bentuk kerusakan fisik pada sistem sambungan kayu yaitu berupa:

1. Sebagian besar kerusakan terjadi pada sampel kayu B dikarenakan tekanan gaya beban patah (P) secara langsung.

2. Kayu A pada umumnya hanya mengalami defleksi (perubahan bentuk) pada bagian yang bersentuhan langsung dengan penampang sambungan akibat tekanan dari sambungan $\mathrm{B}$.

3. Pada sistem sambungan dovetail sebagian besar kerusakan terjadi di kayu B yang mengakibatkan shearing stress pada kayu sambungan.

4. Bentuk kerusakan sambungan juga terjadi pada sistem penguat dowel. Hal tersebut terjadi karena luas penampang berkurang dengan adanya sistem penguat tersebut yang menyebabkan gaya geser bekerja cukup besar pada bagian tersebut.

5. Dalam sistem sambungan lap kerusakan pada umumnya terjadi di kedua belah sisi kayu A maupun B. Hal tersebut dimungkinkan karena titik beban terbagi secara merata pada kedua permukaan kayu yang menyambung, sehingga menghasilkan sistem sambungan yang lebih stabil dan memiliki titik tekan rata-rata lebih tinggi dibandingkan dengan sistem sambungan yang lain.

\section{KESIMPULAN}

Kayu jati memiliki kekuatan tekan tertinggi dalam desain mebel dan kayu sengon memiliki kekuatan tekan terendah pada semua sistem sambungan. sedangkan untuk sistem sambungan lap memiliki kekuatan tekan tertinggi dan sambungan tenon and mortise memiliki kekuatan tekan terendah. Hasil penelitian menunjukkan bahwa terdapat perbedaan bentuk kerusakan disetiap sistem sambungan yang dipengaruhi oleh bentuk sambungan dan jenis kayu yang digunakan. Bahkan jenis kayu yang sama namun dengan sistem sambungan yang berbeda, akan memiliki nilai titik tekan yang berbeda. Hal ini menunjukkan bahwa perlunya pertimbangan yang komprehensif dalam sistem sambungan maupun jenis kayu pada setiap proses perancangan desain mebel, sehingga mampu meminimalisir terjadinya kerusakan serta menambah panjang usia pakai produk mebel.

\section{UCAPAN TERIMA KASIH}

Ucapan terima kasih kepada Sub Laboratorium Workshop Desain Produk ITB dan Laboratorium Material ITB yang telah memfasilitasi penelitian ini.

\section{KONTRIBUSI PENULIS}

Ide, desain, dan rancangan percobaan dilakukan oleh EAS dan IDJ; percobaan dan perlakuan 
pengujian dilakukan oleh EAS; pengumpulan data dan analisis data dilakukan oleh IDJ dan EAS; penulisan manuskrip oleh EAS dan IDJ; perbaikan dan finalisasi mansukrip dilakukan oleh IDJ dan EAS.

\section{DAFTAR PUSTAKA}

Alesina, Inna, \& Ellen Lupton. (2010). Exploring material: creative design for everyday object. Princeton Arcitectural Press, New York.

Cai, L. \& Wang F. (1993). Influence of the stiffness of corner joint on case furniture deflection. Holz Rob Werkst, 5, 406-8.

Haygreen, J.G. \& Bowyer, J. L. (1996). Forest product and wood science: an introduction. Hasil hutan dan ilmu kayu: suatu pengantar. Terjemah Sutjipto A.H. Gadjah Mada University Press, Yogyakarta.

Kementerian Lingkungan Hidup dan Kehutanan. (2018). Data ekspor produk industri kehutanan 2013-Juni 2018. Direktorat Jendral Pengelolaan Hutan Produksi Lestari, Kementerian Lingkungan Hidup dan Kehutanan, Jakarta.

Kementerian Lingkungan Hidup dan Kehutanan. (2018). Data produksi hasil hutan kayu 2013Juni 2018. Direktorat Jendral Pengelolaan Hutan Produksi Lestari, Kementerian Lingkungan Hidup dan Kehutanan, Jakarta.

Kementerian Lingkungan Hidup dan Kehutanan. (2017). Stasistik lingkungan hidup dan kehutanan tahun 2017. Sekretariat Jendral Kementerian Lingkungan Hidup dan Kehutanan, Jakarta.

Kementerian Lingkungan Hidup dan Kehutanan (2018). Status hutan \& kehutanan Indonesia
2018. Kementerian Lingkungan Hidup dan Kehutanan Republik Indonesia, Jakarta.

Kementerian Lingkungan Hidup dan Kehutanan. (2020). Laporan kinerja 2020. Biro Perencanaan, Kementerian Lingkungan Hidup dan Kehutanan, Jakarta.

Kementerian Perindustrian. (2015). Laporan kinerja kementerian perindustrian. Biro Perencanaan, Kementerian Perindustrian, Jakarta.

Krisdianto \& Listya M. D. (2012). Jenis kayu untuk mebel. Pusat Penelitian dan Pengembangan Keteknikan Kehutanan dan Pengolahan Hasil Hutan, Bogor.

Nasution, A. H. \& Hermawan Kartajaya. (2018). Inovasi. Penerbit Andi, Yogyakarta.

Panshin, A.J. \& C. de Zeew. (1980). Textbook of wood technology. Volume I. $3^{\text {rd }}$ ed. McGraw-Hill. New York. 643pp.

Pusat Penelitian dan Pengembangan Hasil Hutan (P3HH). (2008). Petunjuk praktis sifat - sifat dasar jenis kayu Indonesia. Indonesia Sawmill and Woodworking Association.

Sudjana. (2006). Desain dan analisis eksperimen. Bandung: Tarsito.

Sunardianto. (2012). Teknologi kayu bambu dan serat. Fakultas Teknologi Pertanian. Universitas Brawijaya, Malang.

Tankut, A. N. \& Nurgul Tankut. (2010). Section modulus or cornet join in furniture frames as engineering design criteria for their efficient construction. Elsevier Material and Design, 32, 2391-2395.

Wahyudi, I. (2013). Hubungan struktur anatomi kayu dengan sifat kayu, kegunaan dan pengolahannya. Pusat Penelitian dan Pengembangan Keteknikan Kehutanan dan Pengolahan Hasil Hutan, Bogor. 